\title{
SUKSESI KEPEMIMPINAN DALAM PERSPEKTIF PENDIDIKAN KRISTEN
}

\author{
Justice Zeni Zari Panggabean \\ Institut Agama Kristen Negeri Tarutung \\ Email:justice.panggabean@gmail.com
}

\begin{abstract}
Abstrak: Suksesi kepemimpinan adalah suatu peralihan membangun generasi berikutnya. Seorang pemimpin yang berhasil (suksesi kepemimpinan) diawali dari tugas pelayanan bukan sebagai penguasa atau pejabat. Dalam karya ilmiah ini memiliki tujuan penulisan yaitu : pertama, menguraikan tentang kajian teoritis suksesi kepemimpinan. Kedua, memaparkan implikasi pendidikan Kristen terhadap suksesi kepemimpinan. Ketiga, memaparkan perspektif pendidikan Kristen dalam suksesi kepemimpinan. Pada penelitian ini diperoleh hasil bahwa suksesi kepemimpinan memerlukan keseimbangan karakter dan strategi. Pendidikan Kristen berimplikasi sebagai kaidah dan patokan, menjadi norma bagi seorang pemimpin, pikiran, perkataan dan perbuatan. Penelitian ini memiliki kesimpulan bahwa suksesi kepemimpinan dalam perspektif pendidikan Kristen terwujud dari karakter pemimpin yang nyata dalam kebenaran dan kebaikan, yang berdampak pada kualitas, keunggulan yang kompetitif dan berintegritas.
\end{abstract}

\section{Kata-kata kunci: Suksesi Kepemimpinan, Perspektif Pendidikan Kristen}

\begin{abstract}
A leadership succession is a leadership change buid the next generation. A successful leader is gained through serving, not power or authority. The objectives are to elaborate theoretical study on leadership succession, explain the implication of Christian education on leadership succession, and explain Christian perspective regarding leadership succession. The result shows that leadership succession requires balance between character and strategy. Christian education becomes norm and standard for leaders in thought, words, and deed. The conclusion is that from Christian perspective, leadership succession is created from the real leadership character in truth and kindness and it affects the quality, competitive excellence and integrity.
\end{abstract}

\section{Keywords: Leadership Succession, Christian Education Perspective}

\section{PENDAHULUAN}

Pemimpin yang baik tidak "kecanduan kerja" atau "kerajinan kerja". Mereka bekereja keras tanpa diperhamba oleh pekerjaan itu sendiri. Mereka tidak takut akan pekerjaan. Mereka tidak takut untuk membagikan pekerjaan. Seorang pemimpin yang baik melihat pekerjaan sebagai sarana untuk mencapai suatu sasaran yang istimewa. Nilai pekerjaan itu tidak diukur dengan status orang-orang yang melaksanakan suatu pekerjaan khusus. Pemimpin yang baik sebenarnya pemimpin yang mau berkorban dan peduli untuk orang lain serta bersifat melayani. Tetapi, kenyataannya berbeda. Bila kita lihat sekarang para pemimpin kita, dari lapisan bawah sampai lapisan tertinggi, dari pusat hingga ke daerah-daerah. Banyak pemimpin yang hadir dengan tanpa mencerminkan sosok pemimpin yang seharusnya, malah terlihat adanya pemimpin-pemimpin yang jauh dari harapan, tidak peduli dengan nasib anggota yang dilayani, dan hampir tidak pernah berpikir untuk melayani masyarakat. Disinilah dituntut kearifan seorang pemimpin dalam mengambil keputusan 
agar masalah dapat terselesaikan dengan baik Semua pekerjaan dinilai dari kepentingannya dalam mencapai sasaran itu. Namun dari fenomena yang ada menyatakan bahwa suksesi kepemimpinan itu dipandang secara duniawi atau bukan dari suksesi kepemimpinan yang dilihat dari perspektif pendidikan Kristen. Sebagai pemimpin diperlukan pendidikan yang membentuk integritas yang sesuai dengan karakter Kristen. Menjadi pemimpin adalah suatu yang menantang sekaligus menuntut tanggung jawab dan kepiawaian. Menjadi pemimpin bukan sekedar memilih tehnik kepemimpinan, namun membutuhkan pelatihan, penghayatan dan komitmen terhadap panggilan tersebut, seperti pendidikan pemimpin dari tokoh-tokoh Alkitab ${ }^{1}$

Banyak pemimpin yang menganggap dirinya sukses secara duniawi. Seorang pemimpin Kristen tidaklah sama dengan seorang pemimpin masyarakat dalam suatu Negara, organisasi, kelompok, komunitas, keluarga, gereja, perusahaan, negara, dan lain sebagainya. Seorang pemimpin yang berhasil (suksesi kepemimpinan) diawali dari tugas pelayanan bukan sebagai penguasa atau pejabat. Untuk hal ini diperlukan pendekatan pendidikan Kristen bersumber dari Alkitabiah yang membenahi pemimpin dalam tugas dan tanggung jawabnya. $^{2}$

Perspektif pendidikan Kristen, merupakan titik awal dalam membenahi pemimpin yang berhasil (suksesi kepemimpinan. Kehidupan pemimpin yang berhasil membutuhkan kerjasama yang ada dalam komunitas yang mempunyai struktur sosial, identifikasi jati diri, identitas, hasrat untuk mempertahankan kesatuan kehidupan bersama dalam dinamika

${ }^{1}$ John Stott, Isu-isu Global Menetang Kepemimpinan Kristiani, Jakarta: Yayasan Komunikasi Bina Kasih/OMF, 1994, 459.

2 Brian P. Hall, Panggilan akan Pelayanan, Jakarta: BPK Gunung Mulia, 1992, 10 kehidupan yang ada dan pengorganisasian kehidupan dari komunitas tersebut.

Keberhasilan dan keuletan, penuh inspirasi dan motivasi untuk hidup lebih kreatif dan produktif menghantar seorang pemimpin akan berhasil. Kesuksesan atau kegagalan dari pemimpin ditentukan oleh motivasi yang dipengaruhi dari perasaan, sikap dan prilakunya. Sebab banyak hal dalam suatu organisasi atau komunitas yang berdampak dari sikap dan perbuatan kepemimpinan itu sendiri. Fenomena yang ada memperlihatkan bahwa sebagian pemimpin merasa dirinya mampu tanpa belajar dari pendidikan. Pendidikan Kristen merupakan salah satu pendongkrak karakter untuk menjadi pemimpin yang sukses.

Suksesi kepemimpinan dapat terlihat jika seorang pemimpin mampu menjadi pencipta dan pendorong bagi bawahannya untuk menciptakan perkembangan kinerja yang diarahkan sesuai dengan tujuan yang ditetapkan. Suksesi kepemimpinan bukanlah dinilai dari kekuasaan yang memaksa orang lain atau bawahan untuk mengikuti keputusannya atas dasar kepentingan pribadi. ${ }^{3}$ Fenomena ini banyak terjadi dimasyarakat, komunitas atau organisasi, pemimpin lebih mengutamakan keuntungan yang menonjolkan popularitas tanpa mengutamakan kesejahteraan anggota atau orang yang dilayani.

Pendidikan Kristen mengupayakan dan mendidik karakter pemimimpin sebagai pribadi memimpin dengan baik, melayani dan memelihara, serta menjaga komunitas atau masyarakat dalam memberikan dirinya sendiri untuk pelayanan. $^{4} \quad$ Kepemimpinan berkatian dengan pengaruh. Pemimpin yang ideal adalah sesorang yang memiliki hidup dan

${ }^{3}$ Daniel Maedjaja, Prinsip-prinsip kepemimpinan Kristen, Yogyakarta: Yayasan Andy, 1995, 61.

${ }^{4}$ Brian P. Hall, 24 
karakter yang dapat mendorong orang lain untuk meneladaninya. Pemimpin yang baik adalah yang berwibawa, memiliki cara hidup benar dan layak untuk diteladani bukan karena ia berkuasa dan punya gengsi, kepribadian, atau jabatan tertentu. Kepemimpinan adalah suayu daya untuk menggerakkan orang dan mengembangkan mereka agar suatu visi bersama tercapai, maka sangat penting mengetahui cara mengembangkan dan menumbuhkan para pengikut dalam aspek perspektif hidup, nilai, gambar diri dan motivasi. ${ }^{5}$ Sebaliknya, banyak "kepemimpinan" di dunia ini yang tidak lebih dari sekedar rekayasa manusia, mengandalkan ancaman hukuman dan iming-iming imbalan. Ini bukanlah kepemimpinan sejati, melainkan pemerasan. Kepemimpin yang sejati berusaha memberi dorongan bagi orangorang dengan berbicara dari hati kehati, bukan dengan tekakan atau paksaan dari luar. ${ }^{6}$ Arah dari pendidikan Kristen memberikan makna bahwa kepemimpinan sama sekali bukan tentang gaya atau tehnik, melainkan tentang karakter. Dalam penulisan karya ilmiah ini memiliki tujuan penulisan yakni : Pertama, Untuk mengetahui tentang kajian teoritis suksesi kepemimpinan. Kedua, Untuk memaparkan implikasi pendidikan Kristen terhadap suksesi kepemimpinan. Ketiga, Untuk mengetahui kajian perspektif pendidikan Kristen dalam suksesi kepemimpinan.

\section{METODOLOGI PENENELITIAN}

Metodologi yang digunakan dalam artikel ini adalah deskriptif dengan pendekatan kualitatif pada literatur (pustaka), yang berisikan informasi berupa catatan dan data deskriptif dalam teks. Studi pustaka yang dimaksud disini tanpa uji empirik. Penulis menggunakan pandangan teori para ahli tentang

\footnotetext{
${ }^{5}$ Robby I. Chandra, 2009, 1.

${ }^{6}$ Salusu, J. Pengambilan Keputusan Strategik, Jakarta: Grasindo, 2002, 79

7 Jhon White, Kepemimpinan yang handal (mencapai sasaran dengan doa, keberanian, dan tekad yang bulat), Bandung: Yayasan Kalam Hidup
}

pemimpin yang berhasil diawali dalam tugas pelayanan. Penulis menguraikan berbagai teori yang mendeskripsikan suksesi kepemimpinan dalam perspektif kristiani yang tercermin dari karakter pemimpin dan berdampak pada kualitas, keunggulan yang kompetitif dan berintegritas .

\section{SUKSESI KEPEMIMPINAN}

\subsection{Hakikat Kepemimpinan}

$$
\text { Pemimpin adalah seseorang }
$$
dengan wewenang kepemimpinannya mengarahkan bawahannya untuk mengerjakan sebagian dari pekerjaannya dalam mencapai tujuan. Pemimpin pertama-tama harus seorang yang mampu menumbuhkan dan mengembangkan segala yang terbaik dalam diri para bawahannya. ${ }^{7}$ Kepemimpinan merupakan proses pengaruh sosial melalui mana seseorang dapat memperoleh bantuan dari orang lain dalam mencapai sebuah gol. Kepemimpinan adalah kemampuan seseorang mempengaruhi dan memotivasi orang lain untuk melakukan sesuatu sesuai tujuan bersama. Kepemimpinan meliputi proses mempengaruhi dalam menentukan tujuan organisasi, memotivasi perilaku pengikut untuk mencapai tujuan, mempengaruhi untuk memperbaiki kelompok dan budayanya. ${ }^{8}$ Sedangkan kekuasaan adalah kemampuan untuk mempengaruhi orang lain untuk mau melakukan pap yang diinginkan pihak lainnya."The art of influencing and directing meaninsuch away to abatain their willing obedience, confidence, respect, and loyal cooperation in order to accomplish the mission". Kepemimpinan adalah seni untuk mempengaruhi dan menggerakkan orang orang sedemikian rupa untuk memperoleh kepatuhan, kepercayaan,

\footnotetext{
${ }^{8}$ Daniel Maedjaja, Prinsip-prinsip kepemimpinan Kristen, Yogyakarta: Yayasan Andy, 1995, 61.
} 
respek, dan kerjasama secara royal untuk menyelesaikan tugas.

Dari beberapa defenisi diatas disimpulkan bahwa Pemimpin adalah seorang pribadi yang memiliki kecakapan dan kelebihan khususnya kecakapan dan kelebihan di satu bidang, sehingga dia mampu mempengaruhi orang-orang lain untuk bersama-sama melakukan aktivitasaktivitas tertentu, demi pencapaian satu atau beberapa tujuan. ${ }^{9}$

Secara umum seorang pemimpin harus mengerti tentang teori kepemimpinan agar nantinya mempunyai referensi dalam menjalankan sebuah organisasi. Beberapa teori tentang kepemimpinan antara lain :
a) Teori Kepemimpinan Sifat (Trait Theory)
Analisis ilmiah tentang

kepemimpinan berangkat dari pemusatan perhatian pemimpin itu sendiri. Teori sifat berkembang pertama kali di Yunani Kuno dan Romawi yang beranggapan bahwa pemimpin itu dilahirkan, bukan diciptakan yang kemudian teori ini dikenal dengan "The Greatma Theory".

Dalam perkembanganya, teori ini mendapat pengaruh dari aliran perilaku pemikir psikologi yang berpandangan bahwa sifat - sifat kepemimpinan tidak seluruhnya dilahirkan akan tetapi juga dapat dicapai melalui pendidikan dan pengalaman. Sifat - sifat itu antara lain : sifat fisik, mental, dan kepribadian.

b) Teori Kewibawaan Pemimpin

Kewibawaan merupakan faktor penting dalam kehidupan kepemimpinan, sebab dengan faktor itu seorang pemimpin akan dapat mempengaruhi perilaku orang lain baik secara perorangan maupun kelompok sehingga orang tersebut bersedia untuk melakukan apa yang dikehendaki oleh pemimpin.

c) Teori Kepemimpinan Situasi

9 Ayub Ranoh, Kepemimpinan Kharismatis, Jakarta: BPK.Gunung Mulia, 1999, 22

${ }^{10}$ Thariq, Melahirkan pemimpin masa depan, Jakarta: Gema Insani, 2011, 98
Seorang pemimpin harus merupakan seorang pendiagnosa yang baik dan harus bersifat fleksibel, sesuai dengan perkembangan dan tingkat kedewasaan bawahan.Teori Kelompok

Agar tujuan kelompok (organisasi) dapat tercapai, harus ada pertukaran yang positif antara pemimpin dengan pengikutnya. Dari adanya berbagai teori kepemimpinan di atas, dapat diketahui bahwa teori kepemimpinan tertentu akan sangat mempengaruhi gaya kepemimpinan (Leadership Style), yakni pemimpin yang menjalankan fungsi kepemimpinannya dengan segenap integritas, keterampilan dan sikapnya. ${ }^{10}$

\subsection{Karakter Kepemimpinan}

Seorang pemimpin memiliki kerinduan untuk membangun dan mengembangkan mereka yang dipimpinnya sehingga tumbuh banyak pemimpin dalam kelomponya. Hal ini sejalan dengan buku yang ditulis oleh John Maxwell berjudul Developing the Leaders Around You. Keberhasilan seorang pemimpin sangat tergantung dari kemampuannya untuk membangun orang orang di sekitarnya, karena keberhasilan sebuah organisasi sangat tergantung pada potensi sumber daya manusia dalam organisasi tersebut. Jika sebuah organisasi atau masyarakat mempunyai banyak anggota dengan kualitas pemimpin, organisasi atau bangsa tersebut akan berkembang dan menjadi kuat. ${ }^{11}$

Pemimpin yang melayani memiliki kasih dan perhatian kepada mereka yang dipimpinnya. Kasih itu mewujud dalam bentuk kepedulian akan kebutuhan, kepentingan, impian da harapan dari mereka yang dipimpinnya. Seorang pemimpin yang memiliki hati yang melayani adalah akuntabilitas ( accountable ). Istilah akuntabilitas adalah berarti penuh tanggung jawab dan dapat diandalkan. Artinya seluruh perkataan, pikiran dan

11 John Adair, Inspiring Leadership (terjemahan buku London: Thorogood, 2002, 344. 
tindakannya dapat dipertanggungjawabkan kepada publik atau kepada setiap anggota organisasinya. Pemimpin yang melayani adalah pemimpin yang mau mendengar. Mau mendengar setiap kebutuhan, impian, dan harapan dari mereka yang dipimpin. Pemimpin yang melayani adalah pemimpin yang dapat mengendalikam ego dan kepentingan pribadinya melebihi kepentingan public atau mereka yang dipimpinnya. Mengendalikan ego berarti dapat mengendalikan diri ketika tekanan maupun tantangan yang dihadapi menjadi begitu berat,selalu dalam keadaan tenang, penuh pengendalian diri, dan tidak mudah emosi. Suksesi seringkali diartikan sebagai peralihan pimpinan di tingkat puncak, sehingga hanya di posisi puncak tersebut seorang pemimpin dikatakan berhasil. Padahal sebenarnya suksesi dapat menjangkau berbagai lapisan manajerial yang tidak hanya menunjukkan pada jabatan atau kekuasaan namun integritas, loyalitas dan sikap yang diteladani oleh setiap anggota atau bawahan yang bekerjasama mencapai tujuan.

\subsection{Implikasi Pendidikan Kristen Dalam Karakter Pemimpin}

Suksesi Kepemimpinan adalah mendidik dan menyiapkan pemimpinpemimpin visioner sangat diperlukan. Masyarakat membutuhkan pemimpinpemimpin visioner, tetapi pemimpin semacam ini biasanya sulit ditemukan. ${ }^{12}$ Pemimpin-pemimpin visioner yang dikenal dimanapun di seluruh dunia tidak ada yang mendapat pendidikan kepemimpinan secara khusus. Ini tidak berarti bahwa pendidikan kepemimpinan visioner tidak mungkin dilaksanakan. Karena kita menyadari bahwa dunia sangat kekurangan pemimpin visioner, maka alangkah baiknya bila lembaga pendidikan menetapkan visi dan misinya sehubungan dengan pendidikan bagi calon-calon pemimpin visioner. Sebagai bahan pertimbangan, dibawah ini disajikan prinsip-prinsip yang menurut Burt Nanus perlu diusahakan dalam menyiapkan pemimpin-pemimpin visioner.

a) Mengembangkan citra diri (self esteem) anak-anak sedini mungkin

b) Mendorong perkembangan imajinasi dan kreatfitas anak didik

c) Mengebangkan keterampilan berkomunikasi

d) Memberikan prioritas pada keterampilan belajar

e) Mengidentifikasi bakat dan kegemaran anak-anak dan mendorong pengembangannya

f) Mengajarkan untuk mengagumi pemimpin-pemimpin yang besar

g) Mendorong sekolah-sekolah mulai dari taman kanak-kanak hingga universitas untuk menanamkan tanggung jawab dalam menyiapkan pemimpinpemimpin visioner

h) Menyadarkan sekolah-sekolah agar tidak terikat pada obsesi masa silam

i) Mendorong agar sekolah-sekolah memberi kesembatan kepada etiap murid mengalami peran kepemimpinan di sekolah

j) Menekankan pentingnya pelajaran kepemimpinan

k) Mengajarkan kepada murid bagaimana cara kerja organisasi

1) Mengembangkan budaya kepemimpinan dalam sekolah dan lembaga penyelenggara pendidikan.

Bangsa kita khususnya dunia pendidikan, membutuhkan pemimpinpemimpin visioner dengan pola pikir profesional, Hanya mereka yang visioner dna berpola pikir profesional, yang bisa menyusun visi, misi pendidikan yang benar dan dapat mengimplemntasikannya dalam masyarakat multibudaya. Sebagai pemimpin dan pendidik, marilah kita mengembangkan diri kearah itu.

Orang-orang yang menjadi pimpinan harus memutuskan tugas-tugas apa yang perlu dibagikan, dan mengawasi agar semua tugas itu dilaksanakan. Tidak ada seorang pun pemimpin yang dapat memimpin tanpa membagi-bagikan

\footnotetext{
${ }^{12}$ Jhon White, 1995, 65-68
} 
tanggung jawab kepada orang lain, dan barangkali tidak ada lagi batu ujian yang begitu peka mengenai kemempinan yang baik selain cara para pemimpin menangani tugas itu. Motif-motif para pemimpinharus benar. Kegagalan yang paling umum ialah: tidak mendelegasikan atau membagi-bagi tugas. Hal itu mungkin disebabkan ia mempunyai penyakit ingin menggenggam kekuasaan, atau mungkin karena pemimpin itu tidak dapat mempercayai orang lain. Akibatnya, tugas-tugas yang perku tidak pernah dijalankan. ${ }^{13}$

Orang-orang yang mungkin dapat mengerjakannya menjadi jemu dan merasa tidak berguna. Apabila Anda seorang pimpinan, turutilah teladan Nehemia dan delegasikanlah tugas. Janganlah ingin mengerjakan sendiri segala sesuatunya. Para pemimpin harus mau juga melakukan sendiri setiap tugas yang diserahkannya kepada orang lain. Mereka harus bersedia membantu orang-orang yang diserahi tugas-tugas itu. Pemimpin yang baik akan memperhatikan dengan seksama apa kebutuhan rekan-rekan sekerjanya. Kekuasaan pribadi, kemuliaan diri, kemudahan yang menyenangkan diri tidak pernah menjadi prioritas di dalam pikiran pemimpin yang baik. Mereka lebih menaruh minat pada tugas maupun pada kebutuhan orang-orang yang bekerja sama didalamnya. Pemimpin harus memiliki keberanian untuk bertindak, karena pemimpin-pemimpin yang saleh sebagaimana telah kita lihat, tidak hanya menghadapi perlawanan dari luar golongan orang yang setia tetapi juga dari dalam. Yang paling menyakitkan bagi para pemimpin Kristen ialah bila perlawananitu berasal dari orang-orang yang menyebut dirinya Kristen.

Pemimpin merupakan manusia biasa yang memiliki kelemahan. Untuk itu diperlukan pendidikan yang mengarahkan kepemimpinan tersebut berkarakter. Sebagai salah satu tokoh Alkitab yang menjalankan suksesi kepemimpinan adalah Nehemia. Ia menjadi suatu dorongan

${ }^{13}$ Myles Munroe, The Spirit Of

Leadership, Jakarta: Immanuel, 2009, 267 semangat bagi kita. Ia telah menunjukkan kepada kita betapa berharga serta bermanfaatnya menanti pentunjuk Allah di dalam dosa, dan bahwa semua perencanaan yang sungguh-sungguh dimulai di hadirat Allah. ${ }^{14}$

Dari teladan yang diberikannya jelas bagi kita bahwa kepemimpinan yang sejati dan benar harus konsisten dengan kelangsungan pengabdian sebagai seorang hamba. Kita melihat bahwa minatnya terhadap prioritas-prioritas Allah dan terhadap orang Yerusalem menentukan gaya kepemimpinannya. Ia mengajarkan kepada kita betapa berharganya selalu menaruh dalam ingatan kita apa yang menjadi sasaran akhir, dan menempelak dita dengan sikapnya terhadap uang. Kita sudah memperhatikan dia mengalami stress demi stress dan kekuatan demi kekuatan, sementara ia berjalan melintasi pintu-pintu ketakutan menuju kemenangan mutlak.

Akhirnya kita melihat bahwa ia tetap berlari dengan baik dalam tahap akhir pertandingan, sebagaimana yang dilakukannya pada awal mula. Iman dan ketaatan yang membawanya untuk mengambil risiko-risiko besar di hadapan Raja Artahsasta terus termotivasi Nehemia sampai akhir hayatnya.

\subsection{Pendidikan Kristen Membenahi Kepemimpinan Dalam Tindakan Nyata}

Yesus dengan jelas mengajar orang

Kristen untuk memahami kepemimpinan dari sudut pandang yang berlawanan dengan yang umumnya dimengerti oleh para pemimpinan di dunia. Sebagain orang Kristen zaman sekarang menganggap bahwa cara terbaik bagi umat Kristen untuk belajar kepemimpinan adalah dari para tokoh pemimpin duniawi. Alasanya sangat mendasar bagi orang Kristen, kepemimpinan memiliki dimensi kerohanian. Mengarahkan dan memimpin orang lain adalah tugas yang selalu membuat kewajiban rohani tertentu.

Semua orang Kristen dalam segala

14 Henry \& Richard Blackaby, Kepemimpinan Rohani, Batam Centre: Gospel Press 2005, 33 
bentuk kepemimpinan dituntut untuk selalu menjadi pemimpin rohani. Perlu mengingat bahwa peran kepemimpinan adalah tanggung jawab rohani, dan orang-orang yang kitta pimpin adalah amanah dari Tuhan, yang harus kita pertanggungjawabkan pada suatu hari nanti (Mat. 25: 14:30). Kerendahan hati adalah inti dari kepemimpinan, ada banyak orang yang sederhana, lemah lembut, memiliki belas kasih, dan berjiwa melayani, namun tidak cocok berperan sebagai pemimpin.

${ }^{15}$ Kepemimpinan menuntut hati seorang pelayanan, itu tidak berarti seseorang yang berhati melayani pasti bagus dalam memimpin orang lain. ${ }^{16}$

Masih banyak syarat lain yang harus dipenuhi. Alkitab mencatat sejumlah gaya kepemimpinan yang berlainan. Elia adalah seorang nabi yang sering menyendiri, Musa memberikan tanggung jawab kepada orang-orang yang dekat dengannya. Petrus berwatak kasar, Yohanes berhati lembut.

Paulus adalah pemimpin yang dinamis, bahkan ketika ia dibelenggu dengan rantai kemana-mana. Ia memengaruhi orang terutama melalui katakatanya yang berwibawa. Berlatih untuk mengikuti perlombaan, tepatnya seperti itulah cara Paulus menggambarkan kedisiplinan yang ia jalani sebagai seorang pemimpin umat Allah. Ia sama sekali tidak pernah setengah-setengah, atau main-main. Ia jauh lebih serius disbanding atlet lari manapun. Ia ingin memenangkan sebuah lomba yang jauh lebih penting artinya disbanding gelanggang olehraga manpun. Perlombaan yang ia kuti sangat menuntut kerajinan dan kedisiplinan. "Tiap-tiap orang yang turutt mengambil bagian dalam pertandingan, menguasai dirinya dalam segala hal. Mereka berbuat demikian untuk memperoleh suatu hakota yang gana, tapi kita untuk memperoleh mahkota yang abadi”, demikian pesannya dalam 1 Kor. 9:25".

Keberhasilan sejati selalu meminta pengorbanan yang mahal. setiap atlet

15 Eka Dharma Putra, Pergulatan Kehadiran Kristen di Indonesia, Jakarta: BPK.Gunung Mulia, 2010, 27 mengetahui hal itu. Itulah mengapa para atlet mengatur jam tidur, apa yang mereka makan dan cara mereka berlatih. Mereka tidak pernah menganggapnya sebagai hobi atau kegiatan di waktu senggang. Bagi mereka yang ingin berjaya, dituntut sikap nertanggung jawab yang tiada henti. Sebuah kajian cermat atas pelajaran yang diajarkan Yesus dalam tulisan di atas akan mengunkapkan kepemimpinan berikut ini:

a) Kepemimpinan sudah ditetapkan sebelumnya dan bukan preferensi

b) Kepemimpinan adalah jabatan yang dipersiapkan sebelumnya dan bukan preferensi

c) Kepemimpinan adalah jabatan yang dipersiapkan sebelumnya

d) Kepemimpinan menuntut pengorbanan

e) Kepemimpinan bersifat bawaan

f) Kepemimpinan adalah deposito ilahi

g) Kepemimpinan bukan bagi anda, melainkan bagi orang lain

h) Kepemimpinan adalah menjadi diri anda yang sebenarnya demi keuntungan orang lain.

Memahami sifat dasar

kepemimpinan kita mutlak perlu karena cara kita berpikir tentang diri sendiri menentukan sikap dan tindakan kita. Sifat dasar roh memimpin adalah bawaan dari semua manusia untuk mengendalikan dan mengatur, baik lingkungan maupun keadaan. Tanda-tanda terjadinya hubungan kembali dengan roh memimpin adalah: kenyamanan berada bersama sang Pencipta, keyakinan dunia roh, akal sehat dan keamanan internal dan suatu kasih alami terhadap semua manusia. Kepemimpinan sejati bukan suatu metode, teknik, atau sains melainkan suatu sikap. Mempunyai roh kepemimpinan berarti mengerti dan memperlihatkan pola pikir seorang pemimpin. Memanifestasikan roh kepemimpinan adalah masalah menemukan dan memlihara diri sebenarnya supaya membuktikan sifat kepemimpinan.

${ }^{16}$ Jhon Macarthur, Kita kepemimpinan (26 Karakter pemimpin sejati), Jakarta: BPK Gunung mulia, 2009 
Kepemimpinan sejati memberikan alasan kepada orang untuk hidup dan perasaan berarti yang memberikan arti pada kehidupan mereka sehingga mereka merasa diperlukan dan berguna. Kepercayaan dan keyakinan seorang pemimpin mengatur sifat kepemimpinannya. Kepemimpinan efektif memerlukan manajemen prioritas seseorang. Para pemimpin sejati belajar bagaimana membedakan antara apa yang benar-benar penting bagi kehidupan serta pemenuhan tujuan mereka dan apa yang merupakan kebutuhan mendesak tetapi hanya sementara. ${ }^{17}$ Para pemimpin bertekun karena mereka mempunyai suatu pemahaman yang kuat pada tujuan mereka mengettahui ke mana arah yang mereka tuju, dan yakin bahwa mereka akan tiba di sana. Ketekunan mereka adalah suatu manifestasi bahwa mereka memegan keyakinan mengenai masa depan mereka berdasarkan visi yang sudah diberikan kepada mereka untuk kehidupan mereka. ${ }^{18}$ Para pemimpin sejati percaya bahwa pencapaian tujuan mereka bukan pilihan, melainkan suatu kewajiban dan suatu keharusan, sehingga mereka tidak pernah berpikir untuk menyerah. Pemimpin harus mempunyai suatu kombinasi sikap yang mencakup roh yang mencerminkan hati dan gambar sang Pencipta. Kepemimpinan sederhana sekaligus sulit karena menuntut perbaduan, kepercayaan kepada diri sendiri, hasrat pada penugasan seseorang, kasih kepada orang lain, kesediaan dan kapasitas untuk berjalan sendirian, perasaan puas karena sukses orang lain.

\subsection{Ukuran Keberhasilan Seorang Pemimpin Dari Pendidikan Kristen}

Ciri khas Kristen adalah diri Yesus.

Ciri itu tampak dalam pengakuan bahwa Yesus adalah Kristus. Kristus artinya yang diurapi/ dipilih Allah untuk menjadi

17 W. C. H. Predince, Leadership Endures in a Changing, Haggai Institute, 1986, 6.

${ }^{18}$ Ketekunan

http://aweidakai/2008/01/pemimpin-dankepemimpinan-kristen.html.(diakses 12 september 2014)
Penyelamat. Ciri khas Kristen adalah Tuhan (Kurios/orang yang berkuasa atas seseorang/sesuatu,wibawa memerintah atau pemilik yang berkuasa penuh untuk memerintah). ${ }^{19}$ Jadi, ciri khas Kristren adalah adanya pengakuan bahwa Yesus adalah Tuhan yang mempunyai wibawa memerintah atas diri kita. Hans Kung, seorang teolog Roma Katolik yang terkemuka, mengatakan dalam bukunya yang berjudul "On Being A Christian" bahwa predikat/ ciri Kristen adalah:

"The speial figure the most fundamental Characteristic of Christianity is that it considers that Jesus is automatically dercisive, definitive, archetypal, for man relation with God, for man relation with fellowman, and with society". ${ }^{20}$

Itulah ciri khas Kristen dan mengaku seperti itu sebagai pernyataan adalah menunjuk kepada suatu perbuatan yang konkrit dan bukan sduatu perbuatan yang verbal. Implikasi lebih lanjut adalah bahwa segala sesuatu yang diperbuat Yesus menjadi kaidah dan patokan, menjadi norma bagi kita, bagi pikiran kita, perkataan dan perrbuatan kita serta Yesuslah yang nerkuasa penuh atas pikiran, perkataan dan perbuatan kita. Jadi, ciri khas utama serorang Kristen adalah bahwa Tuhan Yesus adalah kaidah/ acuan utama. Predikat seorang Kristen muncul bukan dari orang Kristen, tapi istilah itu muncul sebagai bahan ejekan oleh orang lain, yaitu di Antiokhia kepada orang-orang pengikut Yesus Kristus (Kis 11:26). Kemudian ciriciri atlet yang ada di benak Paulus adalah orang yang disiplin dan menyangkal diri. Ia harus menjaga jadwal latihannya, ada saatsaat ketika cara yang mudah demikian menari; ada saat-saat ketika hal yang benar merupakan hal yang sulit ada

19 Sairin weinata, Identitas dan ciri khas pendidikan Kristen di Indonesia antara konseptual dan operasional, Jakarta: BPK.Gunung Mulia, 2006, 37.

${ }^{20}$ Jhon White, 1995, 65 
saat-saat ketika hal yang benar merupakan hal yang sulit, namun orang Kristen harus melatih diri untuk tidak pernah kendur dalm berusaha seumur hidup membuat jiwanya suci dan kuat. ${ }^{21}$

Paulus menyampaikan secara harfiah merupakan bagian terakhir di dalam hidupnya, yaitu apa yang mengisi hati dan pikiran pemimpin besar ini. Ia ternyata memikirkan orang-orang yang telah menjadi bagian hidupnya. Mereka adalah para calon yang kuat yang dinilainya paling mampu meneruskan kepemimpinannya. Sekalipun ditinggalkan tanpa teman didalam penjara, sekalipun ia berdiri seorang diri ketika mengajukan pembelaan diri di hadapan sidang pengadilan Romawi, ia jelas tidak sendirian dalam hidupnya. Sesungguhnya, karakter sejati dari kepemimpinan Paulus terlihat melalui daftar ringkas orang-orang yang paling dekat di hatinya. Mereka mengisi lembaran-lembaran kisah hidupnya ia pernah membangun tim-tim kemenangan dan akhirnya meraih kemengan. Oleh karena itu, deretan nama tersebut dapat dipakai untuk menggali alas mengapa kepemimpinan Paulus bukanlah suatu kegagalan. Itu pula mengapa pengaruh keteladanannya tetap membahana bagi jutaan kristen, bahkan hingga sekarang. ${ }^{22}$

\section{Suksesi} kepemimpinan dipengaruhi oleh pendidikan Kristen yang merupakan bagian dari pelayanan dalam kehidupan manusia secara umum dan sifatnya universal, untuk menjadikan seorang pemimpin yang disebut gembala sebagai pelayan yang memberikan berkat, (Mzm. 23: 1-6). Sehingga pemimpin Kristen itu adalah gembala yang mengikuti pola kepemimpinan Yesus. Kristen yang artinya sebagai pengikut Kristus, membuat seorang pemimpin harus menjadi orang yang menjadi teladan, seperti Yesus sebagai pemimpin yang diteladani para

${ }^{21}$ Justice, P. Pemahaman Guru PAK dalam aktivitas mengajar berdasarkan 2 Timotius 2:1-7. Tesis, Prodi PAK: Sekolah Tinggi Teologi Baptis Medan. 2012
Rasul, orang percaya pada jamanNya dan suksesNya pemimpin atau orang-orang Kristen hingga saat ini. ${ }^{23}$

Pemimpin Kristen terjadi dalam panggilan Allah, sebagai karunia Allah yang dijalankan untuk mempengaruhi banyak orang dan hidupnyamasing-masing sebagai pemimpin ataupun orang yang dipimpin menjadi diberkati. Apakah dia seorang pemimpin gereja, pemimpin organisasi atau lembaga, dan ataupun pemimpin Negara. Tentu saja artinya, ini tidak dibatasi oleh pembentukan diri sebagai pemimpin yang karena dari lahirnya, oleh karunia yang diberikan Tuhan, tetapi juga adalah dari belajar untuk berbenah atas panggilan Tuhan untuk posisi sebagai pemimpin. Dan sudah tentu meskipun karunia untuk memimpin itu adalah panggilan unuk semua orang, tetapi hanya orang tertentulah yang Tuhan mau pakai untuk menjadi berkat kepada banyak orang (Mat. 22: 17). ${ }^{24}$ Semakin maju seorang pemimpin, akan memiliki kemampuan membenahi sikap menghadapi setiap masalah yang kritis. Tugas pemimpin Kristen adalah menjalankan perintah Sang Gembala Agung dengan sifat dan karakter melalui dan dalam Firman Tuhan, sebagai wujud kedisplinan kepercayaan (karunia) yang diberikan Yesus. Tugas yang dilakukakannya bukanlah pemberian manusia tetapi panggilan Allah (Yeh. 34: 23).

\section{PENUTUP}

\section{Simpulan}

Kata pemimpin, kepemimpinan serta kekuasaan memiliki keterikatan yang tak dapat dipisahkan. Karena untuk menjadi pemimpin bukan hanya berdasarkan suka satu sama lainnya, tetapi banyak faktor. Pemimpin yang berhasil hendaknya memiliki beberapa kriteria yang

\footnotetext{
${ }^{23}$ PolaKepemimpinan, http://sobolimmatius2013/06/materiperkuliahan-program-pascahsarjan.html

${ }^{24}$ Sendjaya, Kepemimpinan Kristen, Yogyakarta: Kairos Book, 2011, 87
} 
tergantung pada sudut pandang atau pendekatan yang digunakan, apakah itu kepribadiannya, keterampilan, bakat, sifat sifatnya, atau kewenangannya yang dimiliki yang mana nantinya sangat berpengaruh terhadap teori maupun gaya kepemimpinan yang akan diterapkan.

\begin{abstract}
Rahasia utama kepemimpinan adalah kekuatan terbesar seorang pemimpin bukan dari kekuasaanya, bukan kecerdasannya, tapi dari kekuatan pribadinya. Seorang pemimpin sejati selalu bekerja keras memperbaiki dirinya sebelum sibuk memperbaiki orang lain. Pemimpin bukan sekedar gelar atau jabatan yang diberikan dari luar melainkan sesuatu yang tumbuh dan berkembang dari dalam diri seseorang. Kepemimpinan lahir dari proses internal (leadership from the inside out).
\end{abstract}

Kepemimpinan yang berhasil, adalah seorang pemimpin yang selalu berbenah diri dalam kuasa kepemimpinannya yang memiliki karakter menetapkan sikap terhadap Tuhan, yaitu; taat dan setia dalam segala situasi, takut dan takluk kepadaNya, mengandalkan Tuhan, memuliakan Tuhan, dan mendahulukan Tuhan pada setiap yang dikerjakan dan diperintahkanya kepada orang yang dipimpin. Disamping itu perlu juga menetapkan sikap terhadap diri sendiri, yaitu; mengenal diri, percaya diri,memiliki harga diri, keutuhan jati diri (integritas), mengetahui krisis dalam diri, perilaku proaktif positip memandang diri, mandiri, dan mampu mengembangkan sikap memandang segala sesuatu yang mengancam diri sebagai memiliki sisi positip dan akan pada akhirnya berakibat positip bagi diri. Juga menetapkan diri terhadap orang lain dengan berpantang menyerah, berupaya untuk mencari makna dan pengalaman sebagai pelajaranberharga di dalam hidup.

Dengan demikian keberhasilan itu tidak terletak pada kekuasaan dan jabatan tetapi oleh usaha, serta upaya pribadinya sendiri yang telah membentuk generasi berikutnya untuk memiliki jiwa kepemimpian. Mewujudkan karakter kepemimpinan itu terhadap organisasinya, komunitas atau lembaganya. Suksesi kepemimpinan dinilai berdasarkan kinerja dan karakter yang mampu membangun orang-orang dipimpin.

\section{Saran}

Sangat diperlukan sekali jiwa kepemimpinan pada setiap pribadi manusia. Jiwa kepemimpinan itu perlu selalu dipupuk dan dikembangkan. Paling tidak untuk memimpin diri sendiri. Oleh karena itu dibutuhkan kualitas pemimpin yang dibekali oleh pendidikan Kristen. Perspektif Pendidikan Kristen memberikan gambaran bahwa untuk membentuk pemimpin yang berhasil dalam menjalankan tugas dan tanggung jawab tidak hanya dari segi jabatan tetapi juga suksesi kepemimpinan itu diperoleh untuk melakukan pelayanan dengan hubungan harmonis, loyalitas dalam membentukn kepemimpinan selanjutnya. Suksesi kepemimpinan perlu dilakukan apabila: pimpinan tidak dapat mencapai tujuan, tidak dapat melakukan loyalitas, tidak menjalin hubungan yang harmonis dengan bawahan dan tidak mampu melakukan tugas dan tanggung jawab.

\section{DAFTAR PUSTAKA}

Ayub Ranoh, Kepemimpinan Kharismatis, Jakarta: BPK.Gunung Mulia, 1999.

Brian P. Hall, Panggilan akan Pelayanan, Jakarta: BPK Gunung Mulia, 1992.

Daniel Maedjaja, Prinsip-prinsip kepemimpinan Kristen, Yogyakarta: Yayasan Andy, 1995.

Daniel Maedjaja, Prinsip-prinsip kepemimpinan Kristen, Yogyakarta: Yayasan Andy, 1995.

Eka Dharma Putra, Pergulatan Kehadiran Kristen di Indonesia, Jakarta: BPK.Gunung Mulia, 2010.

Henry \& Richard Blackaby, Kepemimpinan Rohani, Batam Centre: Gospel Press 2005

Jhon Macarthur, Kita kepemimpinan (26 Karakter pemimpin sejati), Jakarta: BPK Gunung mulia, 2009 
Jhon White, Kepemimpinan yang handal (mencapai sasaran dengan doa, keberanian, dan tekad yang bulat), Bandung: Yayasan Kalam Hidup

John Adair, Inspiring Leadership (terjemahan buku London: Thorogood, 2002 .

John Stott, Isu-isu Global Menetang Kepemimpinan Kristiani, Jakarta: Yayasan Komunikasi Bina Kasih/OMF, 1994.

Justice, P. Pemahaman Guru PAK dalam aktivitas mengajar berdasarkan 2 Timotius 2:1-7. Tesis, Prodi PAK: Sekolah Tinggi Teologi Baptis Medan. 2012

Myles Munroe, The Spirit Of Leadership, Jakarta: Immanuel, 2009.

Robby I. Chandra, Pemimpin dan Memonitoring dalam organisasi, Bandung: Generasi Info Media, 2009.

Sairin weinata, Identitas dan ciri khas pendidikan Kristen di Indonesia antara konseptual dan operasional, Jakarta: BPK.Gunung Mulia, 2006.

Salusu, J. Pengambilan Keputusan Strategik, Jakarta: Grasindo, 2002.

Sendjaya, Kepemimpinan Kristen, Yogyakarta: Kairos Book, 2011.

Thariq, Melahirkan pemimpin masa depan, Jakarta: Gema Insani, 2011.

W. C. H. Predince, Leadership Endures in a Changing, Haggai Institute, 1986.

Yakob Tomatala, Kepemimpinan yang dinamis, Jakarta: YT Leadership Foundation, 1997.

Artikel Internet:

\section{Ketekunan}

http://aweidakai/2008/01/pemimpin-dan-

kepemimpinan-

kristen.html.(diakses12september2014)

PolaKepemimpinan,

http://sobolimmatius2013/06/materi

perkuliahan-program-pascahsarjana.html

(diakses14septermber2014) 